\title{
THE ROLE OF COUNTRY GOVERNANCE ON VALUE-ADDED TAX AND INEQUALITY
}

\author{
Sok-Gee Chan, Zulkufly Ramly
}

\section{Introduction}

Rising income inequality is a growing concern for governments due to its adverse effect on the poverty level, income distribution, social and institutional stability, which in turn impede the economic growth and may lead to political instability. Taxation has long been regarded as the key instrument in a fiscal policy to reduce income inequality via the redistribution of tax revenues to finance public goods and to correct for market-income inequality (Atkinson, 1991). Although prior studies have extensively investigated the effect of taxation on income inequality (Martinez-Vazquez et al., 2012), the findings are inconclusive especially in developing countries (Bird \& Zolt, 2014). The ineffective redistribution role of taxation in developing countries is mainly due to fiscal corruption and tax evasion that distort the distribution process (Richupan, 1984). Consequently, a high percentage of taxes remain uncollected; hence, the value added tax (VAT) system becomes the most popular tool to increase fiscal revenues in developing economies.

Nevertheless the use of VAT to reduce income inequality is debatable due to its regressive nature. This is because lower income earners pay larger percentage of their income on consumption of good and services as compared to higher income earners (Tait, 1991). Consequently, empirical evidences found that VAT widens income inequality (see Leahy et al., 2011; Martinez-Vazquez et al., 2012). Despite of this reason, VAT generates a substantial portion of tax revenue in nearly 130 countries (Keen \& Mintz, 2004) and a quarter of the world's tax revenue (Bye et al., 2012). Besides, VAT is also found to reduce income inequality in developed countries (Bye et al., 2012). This becomes an open debate on the implementation of VAT because distortionary collection of taxes affects economic growth adversely (Narayanan, 2014); hence, countries around the globe have resorted to reform their tax policy by implementing the VAT system. Therefore, this study seeks to examine the impact of VAT on income inequality so as to establish the viability of such policy in reducing the income inequality as claimed by the politicians and prior empirical studies. This study provides an insight to the policy makers on the feasibility of the VAT system to achieve a better income distribution than the traditional personal income tax and corporate tax systems.

In addition, the country governance had been widely documented as a key contributor to the successful implementation of VAT (La Porta et al., 1999). Economists agree that governance is a critical factor in explaining the performance variations across different countries because it affects resources allocation. Therefore, good governance contributes to a good tax system, which is vital for tax distribution process to reduce income inequality. In addition, the tax structure is highly responsive to a governance structure that enhances the collection of tax to be distributed to the productive sectors, as Bird and Zolt (2008) suggested.

We further investigate the impact of VAT on income inequality in developed and developing countries by adding the role of country governance in our research model. We split the sample into developed and developing countries. We argue that varying level of economic development contributes to the differential impacts of VAT on income inequality. To the best of our knowledge this is the first attempt to examine the effect of country governance on the link between VAT and income inequality. Our research focuses on countries with VAT system to determine the governance factors that could improve the link between VAT and income inequality. In doing so, our 
findings enhance the understanding of this link among the policy makers and underscore the importance of improving the country governance to realize the positive effect of the VAT on income equality. Our findings provide insights for better policy implementation by identifying a set of governance factors that contribute to greater efficiency and effectiveness of VAT as a tool for income distribution in different environment setups (e.g., developed versus developing economies).

We seek to identify a sound institutional framework that can be utilized by governments to mitigate the detrimental effects of the VAT system. We believe that the quality of country governance affect the resource allocation and income distribution because it serves as an incentive for the regulators to implement policies that are beneficial for the nation. We make an important contribution to policy implementation with regard to taxation, in particular, the VAT system despite its regressive nature and its potential harmful effect to the economy. Ultimately, we introduce a model for the effective implementation of the VAT to narrow income inequality.

\section{Literature Review and Hypothesis Development}

1.1 VAT and Income Inequality

VAT has been widely used since the 1960s in more than 160 developed and developing nations. The use of VAT enhances the efficiency and effectiveness of the overall taxation system (Keen \& Lockwood, 2010; Narayanan, 2014) to finance socioeconomic development, finance bigger government, and reduce trade deficits (Mitchell, 2005). VAT is found to increase the total tax revenue in both developed and developing economies, for example in New Zealand VAT produced $18 \%$ of the total tax revenue (Hajek, 2001) and more than $50 \%$ in Slovak Republic (Banociova, 2009). Nevertheless, the use of VAT as a tool of revenue generation is highly debatable on the political desk. The proponents of VAT claim that it is less damaging to the country's economy because it is charged at a uniform and relatively low rate. Furthermore, VAT enables the government to generate more revenue to finance the country's growth with greater investment in public infrastructure, education, welfare, healthcare, and national security (Mitchell, 2005), which are vital to reduce the inequality in the economy. Yang and
Zhou (2011) found that undertaking tax reform by implementing an indirect tax such as VAT as the main tax system in China narrowed the gap between the urban and rural income. This is supported by Avi-Yonah (2014) on the use of VAT to finance more social programs in America to reduce the income inequality.

Nevertheless, the impact of VAT is debatable due to its regressive nature. Consequently, VAT negatively affects income distribution because the lower income households spend a higher percentage of their income on VAT than the high income households, thus widening the income gap. Barrett and Wall (2006) found support for this assertion in their study of the distributional impact of VAT from 2000 to 2004 in Ireland. Leahy et al. (2011) also found that lower income households were greatly affected by the VAT. In addition, Poblete (2010) observed that the poverty and income distribution in Chile improved and income tax increased after a cut in the VAT rate. Similarly, Mussa (2014) found that expanding the zero rating coverage and exemption on food, health and education contributed to better poverty reduction and narrows the income inequality. This was possibly due to the fact that without such crucial exemptions the households from lower income group spend higher percentage of their income on VAT than higher income groups.

$H_{1}$ : Higher VAT revenue increases income inequality.

\subsection{The Moderating Role of Country Governance}

Country governance is an important element in attaining an effective and efficient formulation and implementation of government policy, particularly in the redistribution of tax collections. According to Tanzi and Chu (1992), a country with high growth rate may fail to reduce income inequality due to the impairment of the redistributive government policy. Prior studies found that countries with a high level of corruption tend to have lower collection of tax revenues. A high level of corruption reduces the state's ability to allocate funds generated from tax collection for the betterment of the society (Tanzi \& Dvoodi, 1997) and causes significant leakages in tax revenue (Ajaz \& Ahmad, 2010). Studies have observed that rising corruption increases income inequality in Asia (Li et al., 2000), Africa (Kwabena, 2002), Middle Eastern countries (Imam \& Jacobs, 2007), and various 
countries (Gupta et al., 2002). Meanwhile, Adams and Klobodu (2016) found that control for corruption and higher transparency lowered income inequality in the Sub-Saharan African countries.

Instead of focusing on corruption, we include various measures of country governance. Even though country governance is widely recognized as a tool for more efficient and effective tax distribution to reduce income inequality, the empirical evidence is scant (Everest-Phillips \& Sandall, 2009). As La Porta et al. (1999) suggested that the quality of governance is vital in determining the success of government performance. Better governance contributes to economic stability and leads to higher financial development, which in turn increases tax resources (Ajaz \& Ahmad, 2010). Besides, Sumarto et al. (2003) found that poor governance adversely affected the poverty reduction efforts of the Indonesian government. Muinelo-Gallo and Miranda (2014) and Kyriacou et al. (2017) found that country governance is necessary to reduce the income inequality given the fiscal decentralization. Similarly, Chen and Kinkyo (2016) also found that good governance is a critical factor to reduce income inequality. On the other hand, Akram et al. (2011) observed that country governance was positively related to poverty in the long run but not in the short run. Thus, we offer our second hypothesis, as follows:

$\mathrm{H}_{2}$ : Higher VAT revenue reduces income inequality in countries with higher quality governance.

\section{Methodology}

\subsection{Empirical Model}

We first study the impact of value-added tax on income inequality using the system Generalized Method of Moments (GMM) as shown in Equation (1), which is the base equation in our study. We derived the equation based on the growth model.

$$
\begin{aligned}
& \text { Inequality }_{i t}=\alpha_{0}+\alpha_{1} \text { Inequality }_{i t-1}+\alpha_{2} \text { VAT }_{i t}+ \\
& +\alpha_{3} \text { GDP/Cap } \\
& \text { It }+\alpha_{4} \text { Inflation }_{i t}+\alpha_{5} \text { Investment }_{i t}+ \\
& +\alpha_{6} \text { Trade }_{i t}+\alpha_{7} \text { FinDev }_{i t}+\alpha_{8} \text { Literacy }_{i t}+ \\
& +\alpha_{9} \text { GovExp }_{i t}+D_{1} \text { Crisis }+\varphi_{t}(\text { year })_{t}+e_{i t}
\end{aligned}
$$

Where $i_{t h}$ refers to the individual country and $t$ is the time period involved. Our dependent variable is income inequality (Inequality), measured by the Gini coefficient. Income inequality refers to distribution of money income, which has implications for a nation's economic health and policy. The Gini coefficient measures the dispersion of the income on a scale between 0 and 1 where the coefficient of 1 indicates a perfect income inequality, whereas a lower coefficient indicates greater income equality.

The variable of interest in this study is VAT, which is the ratio of VAT collection to government revenue. This ratio is a substitute for the VAT rate due to unavailability of the rate in a time-series manner. In addition, using the ratio of VAT collection to government revenue enables us to assess the commitment of the government towards the implementation of VAT as a tool to generate revenue for funding the country economic development. We predict that VAT is positively related to income inequality due to its regressive nature. Putting it differently, we hypothesize that higher VAT revenue widens income inequality.

We control for GDP per capita (GDP/Cap), inflation (Inflation), investment (Investment), trade openness (Trade), financial development (FinDev), literacy rate (Literacy), and government spending (GovExp) which influence income inequality based on the endogenous growth model. The real GDP per capita with the base year of 2010 is the control variable for economic development. This is important for cross-country analysis as the different countries are characterized by different economic development. Higher real GDP per capita reflects higher average disposable income per individual household, which lowers the income inequality. Inflation is a control variable that captures the effect of the macroeconomic policy environment. An effective macroeconomic policy makes an inflationary episode in the country more stable and hence reduces the income inequality. This is because inflation leads to increases in prices that result in declines in real income (Tanzi, 1977).

We also control for the effect of investment, which is measured by the ratio of gross capital formation to GDP. A higher ratio reduces income inequality due to higher average productivity among individuals. We also used trade openness to reflect the degree of exposure of an economy to external economic shocks. Higher trade openness may increase or reduce income inequality; it may also increase trade 
integration of the country, which would increase income inequality (Milanovic \& Squire, 2007). In addition, we employ financial development to reflect the degree of market integration due to dynamic globalization and liberalization.

The literacy rate measures the education level of the individuals as well as human capital development of a country. Higher education level reduces income inequality due to the "compression" effect (Knight \& Sabot, 1983). According to Zhang (1996), a higher education level enhances labor skills that will lead to an increase in average income and therefore narrows income inequality. The ratio of government spending to GDP constitutes a major source of income distribution towards the economic development and social welfare. Effective and efficient government spending on welfare (education and health) contributes to higher human capital development, which increases the employment opportunities in the economy (Shafique \& Haq, 2006) and, eventually, narrowing income inequality gap. Finally, it is important to control for economic crises (Crisis) because they lead to external shocks that hinder economic development and distort economic policy implementation. Also, economic crises increase the unemployment rate due to the slowdown in the demand for goods and services and, thus, ultimately widen income inequality.

Following In'airat (2014) we use initial GDP as the instrumental variable in our estimation to correct for the endogeneity issues pertaining to the GDP per capita, inflation, investment and trade. The economic condition and investment largely depends on the country's performance.

Next, we add the interaction terms between country governance variables and VAT, as shown in Equation (2) to study the effect of the quality of a country's governance in improving tax collection efficiency and reducing income inequality in which Gov $_{\text {it }}$ is the different types of country governance that we obtained from the International Country Risk Group (ICRG).

$$
\begin{aligned}
& \text { Inequality }_{i t}=\alpha_{0}+\alpha_{1} \text { Inequality }_{\text {it }-1}+ \\
& +\alpha_{2} \text { VAT }_{i t}+\alpha_{3} \text { GDP/Cap } \\
& \text { it } \\
& +\alpha_{4} \text { Inflation }_{i t}+ \\
& +\alpha_{5} \text { Investment }_{i t}+\alpha_{6} \text { Trade }_{i t}+\alpha_{7} \text { FinDev }_{i t}+ \\
& +\alpha_{8} \text { Literacy }_{i t}+\alpha_{9} \text { GovExp }_{i t}+\alpha_{10} \text { Gov }_{i t}+ \\
& +\alpha_{11} \text { Gov }^{*} \text { VAT }_{i t}+D_{1} \text { Crisis }+\varphi_{t} \text { (year }_{t}+e_{i t}
\end{aligned}
$$

According to Akram et al. (2011), good governance is beneficial for reducing poverty and income inequality because it minimizes abuses of power by the authorities. This is especially true in developing countries where institutional problems are the major obstacles in tax collection that hinder the country's development (Ajaz \& Ahmad, 2010). Bird and Zolt (2008) offered support for this assertion when they reported that the tax structure and efficiency are highly responsive to the country's governance, which affects the ability of the economy to fulfill social obligations. Furthermore, good country governance is efficient in protecting private property, able to boost economic activities and macroeconomic stability and effective in managing social conflicts to achieve sustainable economic growth. In this case, we expect $\alpha_{10}$ to reduce income inequality and $\alpha_{11}$ is the parameters to be estimate for the interaction terms of country governance with VAT collection where we expect to be positive if the country governance helps to mitigate the regressive impact of VAT and enhance income distribution.

We employ two-step system GMM to estimate Equations (1) and (2) because income inequality is not a random walk where the performance of the country depends on it past performance. Therefore, system GMM helps to correct for the autocorrelation in income inequality. The GMM technique is superior in addressing potential endogeneity, heteroskedasticity, and autocorrelation problems (Doytch \& Uctum, 2011). Furthermore, system GMM provides more efficient estimates when the instruments used are weak (Blundell \& Bond, 1998).

The sample of this study consists of 105 countries from 1984 to 2014 . The macroeconomic data are obtained from Thomson Datastream whereas the data for country governance are from the ICRG database. We further split the sample into developed and developing countries to study the differential impact of VAT on income inequality in such countries due to the differences in the objective of VAT and government policies. The list of developed and developing countries is from from the United Nations Economic and Social Council of the General Assembly.

\section{Results and Discussions}

We use two-step system GMM estimation to obtain the standard robust estimation in 
determining the impact of VAT on income inequality and the moderating role of the country's governance in the link between VAT and income inequality for the full sample, developed countries, and developing countries. Tab. 2 shows the estimated results for the full sample. Tabs. 3 and 4 present the estimated results for developed and developing countries, respectively. Our base model is Model 1 , in which we examine the main effect of VAT on income inequality. Models 2 through 8 present the moderating effect of the country governance.

Results from Model 1 in Tab. 2 indicate that VAT increases income inequality at a $5 \%$ significance level, which supports the argument that VAT is regressive in nature. This result is in line with the studies of Leahy et al. (2011) and Martinez-Vazquez et al. (2012). In terms of economic significance, an increase in VAT revenue as measured by the ratio of VAT collection to government revenue by one (sample) standard deviation increases income inequality by 0.29 percentage points, which is a relatively small effect. Nevertheless, the significant impact of VAT on income inequality in developed countries is benign (Tab. 3) and VAT reduces income inequality in developing countries a $1 \%$ significance level (Tab. 4). This finding supports our first hypothesis that higher VAT revenue increases income inequality but not in developing economies. VAT may increase revenue collection in developing countries in financing transfers and provision of public goods, which results in reductions in income inequality in the developing countries as compared to developed countries which already have a well-established and efficient tax collection process. This finding corroborates the result of Avi-Yonah (2014), which found that VAT to finance social programs reduced income inequality and led to higher economic growth (Magu, 2013).

Next, we find that higher quality bureaucracy reduces income inequality at a $5 \%$ significance level, thus, supporting our assertion that higher quality bureaucracy mitigates the regressive effect of VAT. The results are consistent for the full sample, developed countries and developing countries. Hence, this finding suggests that improving the quality of bureaucracy is critical to spur the development process by minimizing incidents of abuse of power by government officials and the negative influence of political masters in the government machineries, particularly in tax revenue allocation, thus reducing income inequality.

We also find that high level of corruption control reduces income inequality at a $1 \%$ significance level (Model 3), which is in line with the common expectation that an effective corruption control enhances the government efficiency (Mauro, 1997). Conversely, poor corruption control distorts the allocation of government financial resources, ultimately adversely affecting the distribution of income (see Gupta et al., 2002). The results are consistent across the three samples as shown in Tab. 2. Our results also suggest that higher VAT revenue and a higher level of corruption control reduce income inequality in both developed and developing countries. This is consistent with the findings of $\mathrm{Li}$ et al. (2000) in Asia, Kwabena (2002) in Africa, Imam and Jacobs (2007) in Middle Eastern countries, and a cross-country analysis by Gupta et al. (2002). As highlighted by Tanzi and Dvoodi (1997), a lower level of corruption due to an effective corruption control enhances the allocation of funds generated by tax collection for the society's well-being and reduces the leakages in tax revenue (Ajaz \& Ahmad, 2010).

Third, in terms of democratic accountability the result of Model 4 from Tab. 2 shows that the interaction between democratic accountability and VAT revenues reduces income inequality. This finding indicates that ensuring free and fair elections and responding to the needs of the people are not sufficient to narrow the income gap between the poor and the rich in developing countries. This is easy to understand because governments must have adequate financial resources and be highly responsive to the needs of the people to ensure that the people have access to a good education, public amenities, quality healthcare, and growing economic activities and, thus, enjoy greater access to the wealth of the nation which seems to be weak in developing countries. Nevertheless, we observe that the interaction term of VAT revenue and democratic accountability reduce income inequality in both developed and developing countries. This finding suggests that democratization improves income distribution as educated individuals have more voice in public decisions and, hence, are able to redistribute resources to the poor more efficiently (Chong \& Calderón, 2000). 
The voice of educated individuals is even more crucial in implementing the VAT because it is viewed as a highly regressive tax accompanied by the government's promise to improve the society's economic well-being with better tax collection.

Fourth, Model 5 of Tab. 1 shows the interaction term of the VAT revenue and the government stability reduces income inequality in both developed (1\% significance level) and developing countries (5\% significance level). These results indicate that governments in developed economies are better able to implement policies and programs as declared than developing economies, which are often characterized by inefficiency in the allocation of resources due to market asymmetry. Similar to our results on democratic accountability (in terms of the main effect and economic significance), the result on government stability shows that high stability in the government of the day is not an important factor in narrowing the income gap, but its combination with higher government financial resources in terms of higher collection of the VAT revenue creates the desired effect.

Fifth, the result of Model 6 in Tab. 1 suggests that the combination of higher VAT revenue and high-quality law and order narrows the income gap in our sample countries at a $1 \%$ significance level. Our result implies that an effective and impartial legal system enhances the distribution of government financial resources by ensuring that abuse of power incidents are dealt with seriously, thus minimizing leakage in the government development expenditure due to unscrupulous behavior. In contrast, law and order does not significantly moderate the effect of VAT revenue on income inequality in developing countries. We reckon that this contrasting result may be due to the well-established, stronger, and more impartial legal system in developed countries to minimize misallocation of VAT revenue and ensure its utilization for economic activities to promote more equitable distribution of income for fear of legal reprisal. The weak effect in developing countries may due to weaker legal system that opens up opportunity for abuse of power and failure to implement beneficial policies for the people.

Sixth, we found that the interaction term between political risk and VAT revenue reduces the income inequality by $7.90 \%$ (Model 7 ) and it is statistically significant at a $1 \%$ level for both developed and developing countries. This finding implies that high political stability enables the government to focus on devising and implementing development and economic programs to narrow income inequality. We find that the interaction term of VAT revenue and the political risk rating reduces income inequality at $10 \%$ significance level. This result suggests that higher VAT revenue weakens the positive effect of low political risk on income inequality in all our samples. This may due stable political environment enables the government to operate with greater latitude to implement economic and development programs with certainty, the impact is minimal if the government has strong political power and stability to focus on charting and steering the nations' economic and development strategies uninterrupted by political and social noise. Political and social tensions can derail a government's ability to perform its duty to the people even when the fiscal position is strong. This is supported by Aizenman and Jinjarak (2008), who highlighted that greater political stability increases the efficiency of tax collection and, hence, increases the resources devoted to tax enforcement for the benefit of social well-being.

Finally, in Model 8 of Tab. 2, we find that the interaction term between socioeconomic conditions and VAT revenues reduces income inequality at a $1 \%$ significance level in developed economies. Favorable socioeconomic conditions such as low unemployment, robust consumer confidence, and low poverty reduce income inequality by $1.32 \%$. This result is not surprising because socioeconomic conditions are directly related to the individual and household level of income and distribution of wealth (OECD, 2012). Furthermore, we observe that the interaction term of VAT revenue and socioeconomic conditions has a marginally significant negative relationship with income inequality at a $10 \%$ level. Our finding suggests that improving socioeconomic conditions alone has a stronger impact in reducing the income gap. However, implementation of the VAT system that adds to the government tax revenue appears to weaken this impact from the statistical point of view. This finding implies that government should focus on implementing policies that can boost employment opportunities to improve the socioeconomic condition particularly in 
lower income group to benefits from the VAT implementation (OECD, 2012).

However, we observe a contrasting result for the developing countries in which the socioeconomic conditions positively moderate the effect of VAT revenue and income inequality at a $1 \%$ level, which we note seems to drive the result of the full sample (i.e., marginal moderating effect only). The state of the socioeconomic conditions in developing countries further exacerbates the negative effect of the VAT revenue on income inequality that we observe in the full sample as well as in both the developed and developing countries samples. Putting it differently, the socioeconomic conditions moderate the effect of VAT revenue on income inequality in developing countries but in a negative way. In contrast, the state of socioeconomic conditions in the developed countries reverses the negative effect of VAT revenue on income inequality, which is a desirable outcome. This finding suggests that stable socioeconomic conditions indicate a low degree of socioeconomic pressure and social dissatisfaction that enable the government to focus on implementing VAT revenue allocation policies in a way that reduces the income gap between the poor and the rich without distraction, thereby realizing the redistributive effect of the VAT system.

\section{Tab. 1: Full sample (Part 1)}

\begin{tabular}{|c|c|c|c|c|c|c|c|c|}
\hline Variable & Model 1 & Model 2 & Model 3 & Model 4 & Model 5 & Model 6 & Model 7 & Model 8 \\
\hline Inequality (-1) & $\begin{array}{l}1.033^{\star * *} \\
(0.012)\end{array}$ & $\begin{array}{l}0.326^{* * *} \\
(0.013)\end{array}$ & $\begin{array}{l}0.399^{* * *} \\
(0.022)\end{array}$ & $\begin{array}{l}0.381^{* * *} \\
(0.015)\end{array}$ & $\begin{array}{l}0.987^{* \star *} \\
(0.015)\end{array}$ & $\begin{array}{c}0.984^{\text {***}} \\
(0.022)\end{array}$ & $\begin{array}{l}0.753^{\star * *} \\
(0.024)\end{array}$ & $\begin{array}{c}0.889^{* * *} \\
(0.005)\end{array}$ \\
\hline VAT & $\begin{array}{c}0.004^{* *} \\
(0.002)\end{array}$ & $\begin{array}{l}2.220^{\star *} \\
(1.059)\end{array}$ & $\begin{array}{c}0.388 \\
(0.345)\end{array}$ & $\begin{array}{l}67.074^{* * *} \\
(17.33)\end{array}$ & $\begin{array}{c}0.088^{* *} \\
(0.036)\end{array}$ & $\begin{array}{c}1.035^{\star * *} \\
(0.259)\end{array}$ & $\begin{array}{c}1.570^{*} \\
(0.917)\end{array}$ & $\begin{array}{c}0.586 \\
(0.357)\end{array}$ \\
\hline GDP/Cap & $\begin{array}{l}0.238^{\star * *} \\
(0.038)\end{array}$ & $\begin{array}{l}0.351^{\text {***}} \\
(0.113)\end{array}$ & $\begin{array}{l}0.633^{* * *} \\
(0.242)\end{array}$ & $\begin{array}{c}0.511^{\star *} \\
(0.228)\end{array}$ & $\begin{array}{c}0.231 \\
(0.143)\end{array}$ & $\begin{array}{c}0.124 \\
(0.153)\end{array}$ & $\begin{array}{c}0.126 \\
(0.177)\end{array}$ & $\begin{array}{l}0.032^{* * *} \\
(0.010)\end{array}$ \\
\hline Inflation & $\begin{array}{l}-0.103^{\star * *} \\
(0.014)\end{array}$ & $\begin{array}{c}0.044 \\
(0.045)\end{array}$ & $\begin{array}{l}-0.086 \\
(0.103)\end{array}$ & $\begin{array}{l}-0.023 \\
(0.084)\end{array}$ & $\begin{array}{c}0.017 \\
(0.063)\end{array}$ & $\begin{array}{c}0.003 \\
(0.057)\end{array}$ & $\begin{array}{c}0.093 \\
(0.088)\end{array}$ & 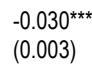 \\
\hline Investment & $\begin{array}{c}1.313 \\
(0.906)\end{array}$ & $\begin{array}{l}16.676^{* * *} \\
(2.487)\end{array}$ & $\begin{array}{l}17.339^{* * *} \\
(3.195)\end{array}$ & $\begin{array}{l}16.162^{* * *} \\
(3.179)\end{array}$ & $\begin{array}{c}5.384^{\star *} \\
(2.679)\end{array}$ & $\begin{array}{c}4.085 \\
(2.512)\end{array}$ & $\begin{array}{c}0.764 \\
(3.125)\end{array}$ & $\begin{array}{l}2.573^{* * *} \\
(0.645)\end{array}$ \\
\hline Trade & $\begin{array}{l}-0.793^{\star *} \\
(0.346)\end{array}$ & $\begin{array}{l}-1.808^{*} \\
(1.015)\end{array}$ & $\begin{array}{l}-0.972 \\
(0.953) \\
\end{array}$ & $\begin{array}{l}-0.446 \\
(1.050) \\
\end{array}$ & $\begin{array}{l}-0.587 \\
(0.571) \\
\end{array}$ & $\begin{array}{l}-0.206 \\
(0.512) \\
\end{array}$ & $\begin{array}{l}-4.146^{\star * *} \\
(0.752)\end{array}$ & $\begin{array}{l}-0.639^{* * *} \\
(0.136)\end{array}$ \\
\hline FinDev & $\begin{array}{l}1.189^{\star \star *} \\
(0.195)\end{array}$ & $\begin{array}{l}6.187^{* * *} \\
(0.858)\end{array}$ & $\begin{array}{l}4.458^{* * *} \\
(0.925)\end{array}$ & $\begin{array}{l}4.335^{\star \star *} \\
(0.904)\end{array}$ & $\begin{array}{c}0.894^{*} \\
(0.496)\end{array}$ & $\begin{array}{c}1.437^{\star *} \\
(0.606)\end{array}$ & $\begin{array}{c}2.136^{\star *} \\
(0.846)\end{array}$ & $\begin{array}{l}2.921^{\text {*** }} \\
(0.113)\end{array}$ \\
\hline Literacy & $\begin{array}{l}-1.839^{\star * *} \\
(0.517)\end{array}$ & $\begin{array}{l}-3.147^{* * *} \\
(0.997)\end{array}$ & $\begin{array}{l}-4.515^{\star *} \\
(1.775) \\
\end{array}$ & $\begin{array}{l}-6.742^{\star \star \star} \\
(1.445)\end{array}$ & $\begin{array}{l}-3.610^{\star \star} \\
(1.540) \\
\end{array}$ & $\begin{array}{l}-3.032^{*} \\
(1.546) \\
\end{array}$ & $\begin{array}{l}-3.062^{* *} \\
(1.205) \\
\end{array}$ & $\begin{array}{l}-1.314^{* * *} \\
(0.259)\end{array}$ \\
\hline GovExp & $\begin{array}{l}-0.229 \\
(1.561)\end{array}$ & $\begin{array}{c}-84.785^{\star * *} \\
(6.894)\end{array}$ & $\begin{array}{c}-75.877^{* * *} \\
(9.599) \\
\end{array}$ & $\begin{array}{c}-82.290^{* * *} \\
(9.225)\end{array}$ & $\begin{array}{l}-6.332^{\star \star} \\
(2.807)\end{array}$ & $\begin{array}{l}-5.981^{* *} \\
(2.802)\end{array}$ & $\begin{array}{l}-5.921 \\
(5.252) \\
\end{array}$ & $\begin{array}{l}-9.807^{* * *} \\
(0.365)\end{array}$ \\
\hline Crisis & $\begin{array}{l}0.994^{\star * *} \\
(0.195)\end{array}$ & $\begin{array}{l}2.200^{* * *} \\
(0.522)\end{array}$ & $\begin{array}{c}0.578 \\
(0.911) \\
\end{array}$ & $\begin{array}{c}1.159 \\
(0.810)\end{array}$ & $\begin{array}{c}0.297 \\
(0.370)\end{array}$ & $\begin{array}{c}0.552 \\
(0.365)\end{array}$ & $\begin{array}{l}3.412^{\star * *} \\
(0.855)\end{array}$ & $\begin{array}{l}0.901^{\text {*** }} \\
(0.059)\end{array}$ \\
\hline Bureaucracy & - & $\begin{array}{l}-2.070^{* * *} \\
(0.254)\end{array}$ & - & - & - & - & - & - \\
\hline $\begin{array}{l}\text { VAT }^{*} \\
\text { Bureaucracy }\end{array}$ & - & $\begin{array}{l}-0.905^{\star *} \\
(0.424)\end{array}$ & - & - & - & - & - & - \\
\hline Corruption & - & - & $\begin{array}{l}-1.165^{\star * *} \\
(0.286)\end{array}$ & - & - & - & - & - \\
\hline $\begin{array}{l}\text { VAT* } \\
\text { Corruption }\end{array}$ & - & - & $\begin{array}{l}-0.174 \\
(0.170)\end{array}$ & - & - & - & - & - \\
\hline Democratic & - & - & - & $\begin{array}{l}0.653^{* *} \\
(0.326)\end{array}$ & - & - & - & - \\
\hline $\begin{array}{l}\text { VAT* }^{*} \\
\text { Democratic }\end{array}$ & - & - & - & $\begin{array}{c}-13.405^{\star \star \star} \\
(3.458)\end{array}$ & - & - & - & - \\
\hline
\end{tabular}




\section{Ekonomie}

\section{Tab. 1: $\quad$ Full sample (Part 2)}

\begin{tabular}{|c|c|c|c|c|c|c|c|c|}
\hline Variable & Model 1 & Model 2 & Model 3 & Model 4 & Model 5 & Model 6 & Model 7 & Model 8 \\
\hline Gstability & - & - & - & - & $\begin{array}{c}0.018 \\
(0.023)\end{array}$ & - & - & - \\
\hline VAT* Gstability & - & - & - & - & $\begin{array}{l}-0.008^{* *} \\
(0.004) \\
\end{array}$ & - & - & - \\
\hline Law & - & - & - & - & - & $\begin{array}{c}0.333 \\
(0.224)\end{array}$ & - & - \\
\hline VAT* Law & - & - & - & - & - & $\begin{array}{l}-0.200^{* * *} \\
(0.050)\end{array}$ & - & - \\
\hline Political Risk & - & - & - & - & - & - & $\begin{array}{l}-0.057^{* * *} \\
(0.020)\end{array}$ & - \\
\hline $\begin{array}{l}\text { VAT }^{*} \text { Political } \\
\text { Risk }\end{array}$ & - & - & - & - & - & - & $\begin{array}{l}-0.022^{*} \\
(0.013)\end{array}$ & - \\
\hline Socioeconomic & - & - & - & - & - & - & - & $\begin{array}{l}-0.536^{\star \star *} \\
(0.026)\end{array}$ \\
\hline $\begin{array}{l}\text { VAT }^{*} \\
\text { Socioeconomic }\end{array}$ & - & - & - & - & - & - & - & $\begin{array}{l}-0.086^{*} \\
(0.052)\end{array}$ \\
\hline Constant & $\begin{array}{l}3.894^{* * *} \\
(0.835)\end{array}$ & $\begin{array}{l}45.828^{\star \star *} \\
(2.123)\end{array}$ & $\begin{array}{l}40.045^{\star * *} \\
(2.793)\end{array}$ & $\begin{array}{l}36.089^{* * *} \\
(2.414)\end{array}$ & $\begin{array}{l}-1.174 \\
(1.769)\end{array}$ & $\begin{array}{c}0.294 \\
(2.385)\end{array}$ & $\begin{array}{l}19.185^{\star \star *} \\
(2.782)\end{array}$ & $\begin{array}{l}8.561^{* * *} \\
(0.453)\end{array}$ \\
\hline Year dummy & Included & Included & Included & Included & Included & Included & Included & Included \\
\hline \multicolumn{9}{|l|}{ Model fits } \\
\hline Wald chi2 & $425.00^{* * *}$ & $137.18^{\star * *}$ & $217.17^{\star * *}$ & $187.223^{* *}$ & $297.59^{* \star *}$ & $456.28^{\star \star *}$ & $573.02^{* \star *}$ & $240.00^{\star * *}$ \\
\hline AR1 & $-3.16^{\star \star \star}$ & $-2.06^{* *}$ & $-2.46^{\star *}$ & $-2.46^{* *}$ & $-2.95^{\star \star \star}$ & $-2.92^{\star \star *}$ & $-3.38^{\star * *}$ & $-3.14^{* * *}$ \\
\hline AR2 & -0.97 & -1.34 & -1.30 & -1.64 & -1.06 & -1.07 & -1.07 & -1.17 \\
\hline $\begin{array}{l}\text { Sargan test } \\
\text { (p-value) }\end{array}$ & $\begin{array}{l}52.91 \\
(0.195)\end{array}$ & $\begin{array}{l}50.21 \\
(0.386)\end{array}$ & $\begin{array}{l}57.09 \\
(0.948)\end{array}$ & $\begin{array}{l}55.21 \\
(0.965)\end{array}$ & $\begin{array}{l}52.50 \\
(0.966)\end{array}$ & $\begin{array}{l}48.96 \\
(0.986)\end{array}$ & $\begin{array}{l}43.10 \\
(0.594)\end{array}$ & $\begin{array}{l}59.55 \\
(0.122)\end{array}$ \\
\hline $\begin{array}{l}\text { No. of } \\
\text { Instruments }\end{array}$ & 85 & 90 & 118 & 118 & 115 & 115 & 88 & 90 \\
\hline $\begin{array}{l}\text { No. of } \\
\text { Observations }\end{array}$ & 2,129 & 2,129 & 2,129 & 2,129 & 2,129 & 2,129 & 2,129 & 2,129 \\
\hline
\end{tabular}

Source: own

Note: This table gives the regression estimation results based on two-stage GMM. Inequality refers to the Gini coefficient in percentage; VAT is the percentage of valued-added tax to GDP; GDP/Cap is the natural logarithm of real GDP per capita; Inflation is the percentage of inflation rate; Investment is the percentage of real gross capital formation to GDP ratio base year of 2010; Trade is the ratio of trade openness; FinDev is the ratio of private credit to GDP; Literacy is the literacy rate measured in percentage; GovExp is the percentage of government expenditure to GDP; Crisis if the dummy variable assigned for economic crisis ( 1 = crisis year; otherwise, 0$)$; Bureaucracy refers to bureaucracy quality; Corruption refers to the corruption index; Democratic refers to democratic accountability; Gstability refers to government stability; Law refers to law and order; Political risk refers to political risk rating; Socioeconomic refers to socioeconomic conditions.

${ }^{*}$ represents significance at $10 \%,{ }^{* *}$ represent significance at $5 \%,{ }^{* * *}$ represent significance at $1 \%$. 


\section{Tab. 2: Developed countries (Part 1)}

\begin{tabular}{|c|c|c|c|c|c|c|c|c|}
\hline Variable & Model 1 & Model 2 & Model 3 & Model 4 & Model 5 & Model 6 & Model 7 & Model 8 \\
\hline Inequality (-1) & $\begin{array}{l}1.025^{\star \star *} \\
(0.015)\end{array}$ & $\begin{array}{l}1.026^{\star \star *} \\
(0.038)\end{array}$ & $\begin{array}{l}0.954^{* \star *} \\
(0.028)\end{array}$ & $\begin{array}{l}0.984^{\star \star \star} \\
(0.029)\end{array}$ & $\begin{array}{l}0.985^{\star \star \star} \\
(0.022)\end{array}$ & $\begin{array}{l}0.946^{\star * *} \\
(0.031)\end{array}$ & $\begin{array}{l}0.977^{\star \star *} \\
(0.030)\end{array}$ & $\begin{array}{l}0.938^{* \star \star} \\
(0.036)\end{array}$ \\
\hline VAT & $\begin{array}{c}3.478 \\
(3.184)\end{array}$ & $\begin{array}{l}11.468^{* *} \\
(5.565)\end{array}$ & $\begin{array}{l}10.100 \\
(9.174)\end{array}$ & $\begin{array}{l}27.775^{\star *} \\
(13.025)\end{array}$ & $\begin{array}{l}11.475 \\
(7.378)\end{array}$ & $\begin{array}{l}25.591^{* *} \\
(9.869)\end{array}$ & $\begin{array}{l}20.594^{* *} \\
(8.974)\end{array}$ & $\begin{array}{l}16.669^{* \star *} \\
(6.364)\end{array}$ \\
\hline GDP/Cap & $\begin{array}{l}0.425^{* * *} \\
(0.047)\end{array}$ & $\begin{array}{l}0.896^{* * *} \\
(0.192)\end{array}$ & $\begin{array}{l}0.474^{* *} \\
(0.225)\end{array}$ & $\begin{array}{l}1.271^{* * *} \\
(0.213)\end{array}$ & $\begin{array}{l}1.074^{\star * *} \\
(0.194)\end{array}$ & $\begin{array}{l}1.268^{* * *} \\
(0.162)\end{array}$ & $\begin{array}{l}1.196^{* * *} \\
(0.179)\end{array}$ & $\begin{array}{l}0.914^{* * *} \\
(0.330)\end{array}$ \\
\hline Inflation & $\begin{array}{l}-0.325^{\star * *} \\
(0.018)\end{array}$ & $\begin{array}{l}-1.902^{\star \star} \\
(0.767)\end{array}$ & $\begin{array}{c}0.215 \\
(0.138)\end{array}$ & $\begin{array}{c}0.052 \\
(0.112)\end{array}$ & $\begin{array}{l}-0.025 \\
(0.080)\end{array}$ & $\begin{array}{c}0.135 \\
(0.099)\end{array}$ & $\begin{array}{c}0.111 \\
(0.089)\end{array}$ & $\begin{array}{l}-0.206 \\
(0.684)\end{array}$ \\
\hline Investment & $\begin{array}{l}5.129^{\star * *} \\
(0.950)\end{array}$ & $\begin{array}{c}3.528 \\
(3.096)\end{array}$ & $\begin{array}{l}6.913^{* * *} \\
(2.618)\end{array}$ & $\begin{array}{l}13.483^{\star \star \star} \\
(3.216)\end{array}$ & $\begin{array}{l}8.814^{\star \star *} \\
(2.665)\end{array}$ & $\begin{array}{l}10.080^{* * *} \\
(2.459)\end{array}$ & $\begin{array}{l}12.651^{* * *} \\
(3.579)\end{array}$ & $\begin{array}{l}6.741^{* * *} \\
(2.588)\end{array}$ \\
\hline Trade & $\begin{array}{l}-3.686^{* * *} \\
(0.575)\end{array}$ & $\begin{array}{l}-0.455 \\
(0.315)\end{array}$ & $\begin{array}{l}-0.132 \\
(0.352)\end{array}$ & $\begin{array}{l}-0.307 \\
(0.269)\end{array}$ & $\begin{array}{l}-0.154 \\
(0.186)\end{array}$ & $\begin{array}{l}-0.571^{* *} \\
(0.250)\end{array}$ & $\begin{array}{l}-0.280 \\
(0.240)\end{array}$ & $\begin{array}{l}-0.445 \\
(0.295)\end{array}$ \\
\hline FinDev & $\begin{array}{l}-0.289 \\
(0.228)\end{array}$ & $\begin{array}{l}-1.475^{* * *} \\
(0.446)\end{array}$ & $\begin{array}{l}-0.933^{* *} \\
(0.433)\end{array}$ & $\begin{array}{l}-0.449 \\
(0.551)\end{array}$ & $\begin{array}{l}-0.618^{*} \\
(0.368)\end{array}$ & $\begin{array}{l}-0.241 \\
(0.435)\end{array}$ & $\begin{array}{l}-0.344 \\
(0.484)\end{array}$ & $\begin{array}{l}-0.060 \\
(0.631)\end{array}$ \\
\hline Literacy & $\begin{array}{l}20.435^{* \star *} \\
(6.934)\end{array}$ & $\begin{array}{c}1.205 \\
(1.828)\end{array}$ & $\begin{array}{l}5.722^{* *} \\
(2.511)\end{array}$ & $\begin{array}{l}1.868 \\
(2.820)\end{array}$ & $\begin{array}{c}3.117 \\
(1.911)\end{array}$ & $\begin{array}{c}2.248 \\
(2.656)\end{array}$ & $\begin{array}{c}2.980 \\
(2.558)\end{array}$ & $\begin{array}{l}5.971^{* *} \\
(2.635)\end{array}$ \\
\hline GovExp & $\begin{array}{c}-21.266^{* \star *} \\
(2.375)\end{array}$ & $\begin{array}{c}-18.871^{* * *} \\
(5.706)\end{array}$ & $\begin{array}{c}-17.056^{\text {*** }} \\
(3.471)\end{array}$ & $\begin{array}{c}-21.226^{* \star \star} \\
(5.098)\end{array}$ & $\begin{array}{l}-8.889^{\star \star *} \\
(2.728)\end{array}$ & $\begin{array}{c}-19.242^{* \star *} \\
(3.455)\end{array}$ & $\begin{array}{c}-18.879^{* * *} \\
(3.514)\end{array}$ & $\begin{array}{c}-24.304^{* \star *} \\
(6.760)\end{array}$ \\
\hline Crisis & $\begin{array}{l}0.368^{\star * *} \\
(0.121)\end{array}$ & $\begin{array}{l}1.590^{* * *} \\
(0.488)\end{array}$ & $\begin{array}{c}0.073 \\
(0.525)\end{array}$ & $\begin{array}{c}0.415 \\
(0.527)\end{array}$ & $\begin{array}{c}0.613 \\
(0.520)\end{array}$ & $\begin{array}{c}0.273 \\
(0.492)\end{array}$ & $\begin{array}{c}0.404 \\
(0.444)\end{array}$ & $\begin{array}{l}1.533^{* \star *} \\
(0.472)\end{array}$ \\
\hline Bureaucracy & - & $\begin{array}{c}0.494^{*} \\
(0.292)\end{array}$ & - & - & - & - & - & - \\
\hline $\begin{array}{l}\text { VAT* } \\
\text { Bureaucracy }\end{array}$ & - & $\begin{array}{l}-0.017^{* * *} \\
(0.004)\end{array}$ & - & - & - & - & - & - \\
\hline Corruption & - & - & $\begin{array}{l}-0.045 \\
(0.167) \\
\end{array}$ & - & - & - & - & - \\
\hline VAT* Corruption & - & - & $\begin{array}{l}-0.013^{* * *} \\
(0.003)\end{array}$ & - & - & - & - & - \\
\hline Democratic & - & - & - & $\begin{array}{l}-0.216 \\
(0.136)\end{array}$ & - & - & - & - \\
\hline VAT* Democratic & - & - & - & $\begin{array}{l}-0.009^{* \star *} \\
(0.002)\end{array}$ & - & - & - & - \\
\hline Gstability & - & - & - & - & $\begin{array}{l}-0.203^{* \star *} \\
(0.058)\end{array}$ & - & - & - \\
\hline VAT* Gstability & - & - & - & - & $\begin{array}{l}-0.006^{* * *} \\
(0.001)\end{array}$ & - & - & - \\
\hline Law & - & - & - & - & - & $\begin{array}{l}-0.275 \\
(0.185)\end{array}$ & - & - \\
\hline VAT* Law & - & - & - & - & - & $\begin{array}{l}-0.007^{* * *} \\
(0.001)\end{array}$ & - & - \\
\hline Political Risk & - & - & - & - & - & - & $\begin{array}{l}-0.016 \\
(0.014)\end{array}$ & - \\
\hline $\begin{array}{l}\text { VAT* Political } \\
\text { Risk }\end{array}$ & - & - & - & - & - & - & $\begin{array}{l}-0.001^{* * *} \\
(0.000)\end{array}$ & - \\
\hline Socioeconomic & - & - & - & - & - & - & - & $\begin{array}{l}-0.009 \\
(0.063)\end{array}$ \\
\hline $\begin{array}{l}\text { VAT }^{*} \\
\text { Socioeconomic }\end{array}$ & - & - & - & - & - & - & - & $\begin{array}{l}-0.005^{\star \star *} \\
(0.002)\end{array}$ \\
\hline
\end{tabular}


Tab. 2: Developed countries (Part 2)

\begin{tabular}{|c|c|c|c|c|c|c|c|c|}
\hline Variable & Model 1 & Model 2 & Model 3 & Model 4 & Model 5 & Model 6 & Model 7 & Model 8 \\
\hline Constant & $\begin{array}{l}13.137^{* *} \\
(6.800)\end{array}$ & $\begin{array}{l}-9.820^{\star \star *} \\
(3.536)\end{array}$ & $\begin{array}{l}-6.574^{*} \\
(3.498)\end{array}$ & $\begin{array}{c}-12.982^{* * *} \\
(3.057)\end{array}$ & $\begin{array}{c}-12.093^{* * *} \\
(2.336)\end{array}$ & $\begin{array}{c}-11.232^{* \star *} \\
(2.855)\end{array}$ & $\begin{array}{c}-12.880^{\star \star *} \\
(2.771)\end{array}$ & $-11.415^{\star * *}$ \\
\hline Year dummy & Included & Included & Included & Included & Included & Included & Included & Included \\
\hline \multicolumn{9}{|l|}{ Model fits } \\
\hline Wald chi2 & $482.92^{\star \star \star}$ & 115.70 & $622.00^{* * *}$ & $120.72^{* * *}$ & $141.75^{\star \star \star}$ & $130.01^{\star * *}$ & $171.87^{\star * *}$ & $292.71^{\text {*** }}$ \\
\hline AR1 & $-3.67^{\star \star *}$ & $-1.68^{*}$ & $-3.40^{\star * *}$ & $-3.46^{\star \star *}$ & $-3.56^{\star \star \star}$ & $-3.45^{\star \star \star}$ & $-3.51^{\star \star *}$ & $-2.86^{* * *}$ \\
\hline AR2 & 0.49 & 0.59 & -0.02 & -0.30 & -0.21 & -0.15 & -0.24 & -0.17 \\
\hline $\begin{array}{l}\text { Sargan test } \\
\text { (p-value) }\end{array}$ & $\begin{array}{l}22.98 \\
(0.290)\end{array}$ & $\begin{array}{l}13.50 \\
(0.636) \\
\end{array}$ & $\begin{array}{l}18.65 \\
(0.413)\end{array}$ & $\begin{array}{l}10.16 \\
(0.927) \\
\end{array}$ & $\begin{array}{l}13.59 \\
(0.755) \\
\end{array}$ & $\begin{array}{l}16.45 \\
(0.561) \\
\end{array}$ & $\begin{array}{l}12.98 \\
(0.793) \\
\end{array}$ & $\begin{array}{l}14.62 \\
(0.552) \\
\end{array}$ \\
\hline $\begin{array}{l}\text { No. of } \\
\text { Instruments }\end{array}$ & 31 & 29 & 31 & 31 & 31 & 31 & 31 & 29 \\
\hline $\begin{array}{l}\text { No. of } \\
\text { Observations }\end{array}$ & 897 & 897 & 897 & 897 & 897 & 897 & 897 & 897 \\
\hline
\end{tabular}

Source: own

Note: This table gives the regression estimation results based on two-stage GMM. Inequality refers to the Gini coefficient in percentage; VAT is the percentage of valued-added tax to GDP; GDP/Cap is the natural logarithm of real GDP per capita; Inflation is the percentage of inflation rate; Investment is the percentage of real gross capital formation to GDP ratio base year of 2010; Trade is the ratio of trade openness; FinDev is the ratio of private credit to GDP; Literacy is the literacy rate measured in percentage; GovExp is the percentage of government expenditure to GDP; Crisis if the dummy variable assigned for economic crisis ( 1 = crisis year; otherwise, 0$)$; Bureaucracy refers to bureaucracy quality; Corruption refers to the corruption index; Democratic refers to democratic accountability; Gstability refers to government stability; Law refers to law and order; Political risk refers to political risk rating; Socioeconomic refers to socioeconomic conditions.

${ }^{*}$ represents significance at $10 \%,{ }^{* *}$ represent significance at $5 \%,{ }^{* * *}$ represent significance at $1 \%$.

\section{Conclusion}

This study examines the effect of VAT revenue on income inequality and the role of country governance to mitigate the negative impact of VAT. We also examine the potential differential effect of the country's governance on the relationship between VAT revenue and income inequality by splitting our sample into developed and developing countries. The results suggest that VAT increases income inequality, which further reinforces its regressive nature. However, we argue that the link between a tax system and income inequality is not straightforward due to the effect of country governance. Our results suggest that quality of bureaucracy, democratic accountability, government stability and law and order strongly moderate the link between VAT and income inequality. In particular, the interaction terms of each governance element and VAT narrow the income inequality, suggesting that they play a positive role in the allocation of VAT revenue.

On the other hand, political risk rating and socioeconomic conditions play a marginal moderating role in the same relationship. We conclude that higher quality governance helps to narrow the income inequality in countries with higher VAT collection in both developed and developing countries. Therefore, our findings highlight that the redistributive effect of VAT is contingent on the quality of a country's governance structure; otherwise, VAT is regressive and widens income inequality. Our findings reinforce the assertion of Bird and Zolt (2008) that the tax structure is highly responsive to the governance structure that ensures the tax collected is distributed to productive sectors to support development processes, and are consistent with the finding of Ajaz and Ahmad (2010) and Akram et al. (2011).

The findings of our study have several policy implications. First, the government needs to put in place quality governance measures to ensure effective distribution of VAT revenue for social welfare programs and economic activities in reducing the negative effect of the VAT on income inequality. Second, as the quality of country governance affects the resource 


\section{Tab. 3: Developing countries (Part 1)}

\begin{tabular}{|c|c|c|c|c|c|c|c|c|}
\hline Variable & Model 1 & Model 2 & Model 3 & Model 4 & Model 5 & Model 6 & Model 7 & Model 8 \\
\hline Inequality (-1) & $\begin{array}{l}0.598^{* \star *} \\
(0.007)\end{array}$ & $\begin{array}{l}0.596^{\star * *} \\
(0.007)\end{array}$ & $\begin{array}{l}0.905^{\star * *} \\
(0.003)\end{array}$ & $\begin{array}{l}0.085^{* *} \\
(0.035)\end{array}$ & $\begin{array}{l}0.740^{* * *} \\
(0.017)\end{array}$ & $\begin{array}{l}0.617^{\star \star *} \\
(0.003)\end{array}$ & $\begin{array}{l}0.767^{\star * *} \\
(0.017)\end{array}$ & $\begin{array}{l}0.883^{* * *} \\
(0.014)\end{array}$ \\
\hline VAT & $\begin{array}{c}-20.346^{\star \star *} \\
(0.277)\end{array}$ & $\begin{array}{l}-9.413^{\star * *} \\
(2.920)\end{array}$ & $\begin{array}{l}-2.025^{\star * *} \\
(0.517)\end{array}$ & $\begin{array}{c}-46.302^{* * *} \\
(6.905)\end{array}$ & $\begin{array}{c}-12.233^{* *} \\
(5.335)\end{array}$ & $\begin{array}{l}-6.465 \\
(4.012)\end{array}$ & $\begin{array}{l}55.129^{* * *} \\
(16.693)\end{array}$ & $\begin{array}{c}-35.247^{\star * *} \\
(8.037)\end{array}$ \\
\hline GDP/Cap & $\begin{array}{l}-0.026^{* *} \\
(0.013)\end{array}$ & $\begin{array}{l}-0.025^{\star \star} \\
(0.010)\end{array}$ & $\begin{array}{l}-0.157^{\star * *} \\
(0.002)\end{array}$ & $\begin{array}{l}-0.565^{\star * *} \\
(0.170)\end{array}$ & $\begin{array}{l}-0.361^{* * *} \\
(0.086)\end{array}$ & $\begin{array}{l}-0.111^{\star \star \star} \\
(0.029)\end{array}$ & $\begin{array}{l}-0.087 \\
(0.088) \\
\end{array}$ & $\begin{array}{l}-0.089 \\
(0.144) \\
\end{array}$ \\
\hline Inflation & $\begin{array}{l}0.045^{\star \star *} \\
(0.002)\end{array}$ & $\begin{array}{l}0.031^{\star * *} \\
(0.001)\end{array}$ & $\begin{array}{l}0.060^{* * *} \\
(0.001)\end{array}$ & $\begin{array}{l}0.300^{* * *} \\
(0.085)\end{array}$ & $\begin{array}{l}0.278^{* * *} \\
(0.022)\end{array}$ & $\begin{array}{c}0.050 \\
(0.043)\end{array}$ & $\begin{array}{l}0.176^{\star * *} \\
(0.049)\end{array}$ & $\begin{array}{l}0.449^{* * *} \\
(0.110)\end{array}$ \\
\hline Investment & $\begin{array}{c}-15.740^{\star * *} \\
(0.599)\end{array}$ & $\begin{array}{c}-13.162^{\star * *} \\
(0.583)\end{array}$ & $\begin{array}{l}-3.024^{* * *} \\
(0.257)\end{array}$ & $\begin{array}{l}-9.283^{* *} \\
(4.455)\end{array}$ & $\begin{array}{c}-11.877^{* \star *} \\
(1.247)\end{array}$ & $\begin{array}{c}-17.847^{* \star *} \\
(0.840)\end{array}$ & $\begin{array}{l}-6.942^{\star * *} \\
(1.733)\end{array}$ & $\begin{array}{l}-3.138^{*} \\
(1.618)\end{array}$ \\
\hline Trade & $\begin{array}{l}3.498^{\star \star *} \\
(0.110)\end{array}$ & $\begin{array}{l}2.809^{\star * *} \\
(0.153)\end{array}$ & $\begin{array}{l}0.335^{\star * *} \\
(0.100)\end{array}$ & $\begin{array}{c}2.184 \\
(1.449)\end{array}$ & $\begin{array}{l}0.779^{* * *} \\
(0.273)\end{array}$ & $\begin{array}{l}2.956^{\star \star *} \\
(0.225)\end{array}$ & $\begin{array}{c}0.217 \\
(0.561)\end{array}$ & $\begin{array}{l}1.005^{\star * *} \\
(0.367)\end{array}$ \\
\hline FinDev & $\begin{array}{l}-0.422^{\star \star *} \\
(0.044)\end{array}$ & $\begin{array}{l}-0.632^{\star * *} \\
(0.077)\end{array}$ & $\begin{array}{l}-0.075^{\star * *} \\
(0.011)\end{array}$ & $\begin{array}{l}-4.860^{* * *} \\
(0.987)\end{array}$ & $\begin{array}{l}-3.799^{* * *} \\
(0.331)\end{array}$ & $\begin{array}{l}5.533^{\star * *} \\
(0.304)\end{array}$ & $\begin{array}{l}3.301^{* * *} \\
(0.459)\end{array}$ & $\begin{array}{c}0.309 \\
(0.369)\end{array}$ \\
\hline Literacy & $\begin{array}{l}-4.027^{\star \star} \\
(1.729)\end{array}$ & $\begin{array}{l}-4.493^{\star * *} \\
(1.225)\end{array}$ & $\begin{array}{l}-1.504^{* * *} \\
(0.111)\end{array}$ & $\begin{array}{c}-15.354^{\star * *} \\
(5.132)\end{array}$ & $\begin{array}{l}-3.460^{* * *} \\
(0.431)\end{array}$ & $\begin{array}{l}-3.735^{\star \star \star} \\
(0.233)\end{array}$ & $\begin{array}{l}-1.015 \\
(0.819) \\
\end{array}$ & $\begin{array}{l}-5.233^{* * *} \\
(0.934)\end{array}$ \\
\hline GovExp & $\begin{array}{c}-12.696^{\star \star \star} \\
(0.830)\end{array}$ & $\begin{array}{l}-2.541^{* * *} \\
(0.872)\end{array}$ & $\begin{array}{l}-3.509^{* * *} \\
(0.199)\end{array}$ & $\begin{array}{c}-12.436^{\star * *} \\
(4.855)\end{array}$ & $\begin{array}{c}-55.176^{* \star \star} \\
(3.494)\end{array}$ & $\begin{array}{c}-31.899^{\star \star \star} \\
(2.701)\end{array}$ & $\begin{array}{c}-40.288^{* * *} \\
(3.993)\end{array}$ & $\begin{array}{c}-23.786^{* * *} \\
(2.936)\end{array}$ \\
\hline Crisis & $\begin{array}{l}0.093^{* * *} \\
(0.036)\end{array}$ & $\begin{array}{l}0.106^{\star * *} \\
(0.036)\end{array}$ & $\begin{array}{l}1.102^{* * *} \\
(0.046)\end{array}$ & $\begin{array}{c}0.438^{*} \\
(0.257)\end{array}$ & $\begin{array}{l}0.708^{* * *} \\
(0.215)\end{array}$ & $\begin{array}{c}0.309^{*} \\
(0.174)\end{array}$ & $\begin{array}{l}1.277^{\star * *} \\
(0.292)\end{array}$ & $\begin{array}{l}1.482^{* * *} \\
(0.375)\end{array}$ \\
\hline Bureaucracy & - & $\begin{array}{l}2.002^{* * *} \\
(0.122)\end{array}$ & - & - & - & - & - & - \\
\hline $\begin{array}{l}\text { VAT* } \\
\text { Bureaucracy }\end{array}$ & - & $\begin{array}{l}-3.440^{* * *} \\
(1.003) \\
\end{array}$ & - & - & - & - & - & - \\
\hline Corruption & - & - & $\begin{array}{l}0.155^{* * *} \\
(0.015)\end{array}$ & - & - & - & - & - \\
\hline VAT $^{\star}$ Corruption & - & - & $\begin{array}{l}-3.709^{* * *} \\
(0.106) \\
\end{array}$ & - & - & - & - & - \\
\hline Democratic & - & - & - & $\begin{array}{l}1.172^{\star * *} \\
(0.252) \\
\end{array}$ & - & - & - & - \\
\hline VAT* Democratic & - & - & - & $\begin{array}{l}-3.284^{* * *} \\
(0.848)\end{array}$ & - & - & - & - \\
\hline Gstability & - & - & - & - & $\begin{array}{l}0.272^{* * *} \\
(0.062) \\
\end{array}$ & - & - & - \\
\hline VAT $^{*}$ Gstability & - & - & - & - & $\begin{array}{l}-1.328^{* *} \\
(0.596) \\
\end{array}$ & - & - & - \\
\hline Law & - & - & - & - & - & $\begin{array}{l}-0.873^{\star * *} \\
(0.127) \\
\end{array}$ & - & - \\
\hline VAT $^{*}$ Law & - & - & - & - & - & $\begin{array}{l}-1.367 \\
(1.338) \\
\end{array}$ & - & - \\
\hline Political Risk & - & - & - & - & - & - & $\begin{array}{l}-0.013 \\
(0.020)\end{array}$ & - \\
\hline $\begin{array}{l}\text { VAT* Political } \\
\text { Risk }\end{array}$ & - & - & - & - & - & - & $\begin{array}{l}-0.870^{\star \star *} \\
(0.259)\end{array}$ & - \\
\hline Socioeconomic & - & - & - & - & - & - & - & $\begin{array}{l}-0.707^{* * *} \\
(0.090)\end{array}$ \\
\hline $\begin{array}{l}\text { VAT* } \\
\text { Socioeconomic }\end{array}$ & - & - & - & - & - & - & - & $\begin{array}{l}6.288^{* * *} \\
(1.291)\end{array}$ \\
\hline
\end{tabular}




\section{Tab. 3: Developing countries (Part 2)}

\begin{tabular}{l|c|c|c|c|c|c|c|c}
\multicolumn{1}{c|}{ Variable } & Model 1 & Model 2 & Model 3 & Model 4 & Model 5 & Model 6 & Model 7 & Model 8 \\
\hline Constant & $\begin{array}{c}19.333^{* * *} \\
(1.523)\end{array}$ & $\begin{array}{c}20.159^{* * *} \\
(0.990)\end{array}$ & $\begin{array}{c}6.120^{* * *} \\
(0.295)\end{array}$ & $\begin{array}{c}57.320^{* * *} \\
(4.303)\end{array}$ & $\begin{array}{c}20.609^{* * *} \\
(1.348)\end{array}$ & $\begin{array}{c}31.308^{* * *} \\
(0.304)\end{array}$ & $\begin{array}{c}16.563^{* * *} \\
(1.931)\end{array}$ & $\begin{array}{c}8.754^{* * *} \\
(1.198)\end{array}$ \\
\hline Year dummy & Included & Included & Included & Included & Included & Included & Included & Included \\
\hline Model fits & & & & & & & & \\
\hline Wald chi2 & $468.00^{* * *}$ & $222.00^{* * *}$ & $287.00^{* * *}$ & $431.37^{* * *}$ & $561.22^{* * *}$ & $599.00^{* * *}$ & $840.34^{* * *}$ & $121.00^{* * *}$ \\
\hline AR1 & $-2.45^{* *}$ & $-2.46^{* *}$ & $-2.59^{* *}$ & $-2.32^{* *}$ & $-2.53^{* *}$ & $-2.46^{* *}$ & $-2.59^{* *}$ & $-2.59^{* *}$ \\
\hline AR2 & -1.22 & -1.21 & -1.09 & -1.24 & -1.25 & -1.33 & -1.23 & -1.10 \\
\hline $\begin{array}{l}\text { Sargan test } \\
\text { (p-value) }\end{array}$ & $\begin{array}{c}42.72 \\
(0.724)\end{array}$ & $\begin{array}{c}44.42 \\
(0.580)\end{array}$ & $\begin{array}{c}35.54 \\
(0.815)\end{array}$ & $\begin{array}{c}37.57 \\
(0.666)\end{array}$ & $\begin{array}{c}35.95 \\
(0.733)\end{array}$ & $\begin{array}{c}47.18 \\
(0.424)\end{array}$ & $\begin{array}{c}32.72 \\
(0.786)\end{array}$ & $\begin{array}{c}34.55 \\
(0.442)\end{array}$ \\
\hline $\begin{array}{l}\text { No. of } \\
\text { Instruments }\end{array}$ & 60 & 60 & 57 & 55 & 55 & 59 & 53 & 47 \\
\hline $\begin{array}{l}\text { No. of } \\
\text { Observations }\end{array}$ & 1,232 & 1,232 & 1,232 & 1,232 & 1,232 & 1,232 & 1,232 & 1,232 \\
\hline
\end{tabular}

Source: own

Notes: This table gives the regression estimation results based on two-stage GMM. Inequality refers to the Gini coefficient in percentage; VAT is the percentage of valued-added tax to GDP; GDP/Cap is the natural logarithm of real GDP per capita; Inflation is the percentage of inflation rate; Investment is the percentage of real gross capital formation to GDP ratio base year of 2010; Trade is the ratio of trade openness; FinDev is the ratio of private credit to GDP; Literacy is the literacy rate measured in percentage; GovExp is the percentage of government expenditure to GDP; Crisis if the dummy variable assigned for economic crisis ( 1 = crisis year otherwise 0 ); Bureaucracy refers to bureaucracy quality; Corruption refers to the corruption index; Democratic refers to democratic accountability; Gstability refers to government stability; Law refers to law and order; Political risk refers to political risk rating; Socioeconomic refers to socioeconomic conditions.

${ }^{*}$ represents significance at $10 \%,{ }^{* *}$ represent significance at $5 \%,{ }^{* * *}$ represent significance at $1 \%$.

allocation and income distribution it provides an incentive for the regulators to implement taxation policies and at simultaneously improve the country's institutional quality to achieve the desired effect of reducing income inequality through fiscal policy. Third, the governments of developing countries need to effectively manage the degree of socioeconomic conditions that could distract them from focusing on implementing VAT to eradicate poverty and raise the income level of the poor segment of society. Finally, the developing economies should strive to avoid political instability that could distract them from devising and implementing development and economic programs to narrow income inequality.

This work was supported by the Fundamental Research Grant FP034-2014B from the Ministry of Education Malaysia.

\section{References}

Adam, S., \& Klobodu, E. K. M. (2016). Financial Development, Control of Corruption and Income Inequality. International Review of Applied Economics, 30(6), 790-808. https://dx.doi.org/10.1080/02692171.2016.1208740.

Aizenman, J., \& Jinjarak, Y. (2008). The Collection Efficiency of the Value Added Tax: Theory and International Evidence. Journal of International Trade and Economic Development, 1(7), 391-410. https://dx.doi. org/10.1080/09638190802137059.

Ajaz, T., \& Ahmad, E. (2010). The Effect of Corruption and Governance on Tax Revenues. Pakistan Development Review, 49(4), 405-417.

Akram, Z., Wajid, S., Mahmood, T., \& Sarwar, S. (2011). Impact of Poor Governance and Income Inequality of Poverty in Pakistan. Far East Journal of Psychology and Business, 4(3), 43-55.

Atkinson, T. (1991). Modern Public Finance. Aldershot, UK: Edward Elgar. 
Avi-Yonah, R. (2014). Taxation and Inequality: A Case for the VAT. Challenge, 57(3), 97-104. https://dx.doi.org/10.2753/05775132570305.

Banociova, A. (2009). The Analysis of Value Added Tax in the Slovak Republic. E\&M Ekonomie a Management, 12(4), 104-115.

Barrett, A., \& Wall, C. (2006). The Distributional Impact of Ireland's Indirect Tax System. Dublin: Combat Poverty Agency. Retrieved June 1, 2016, from http://www.cpa.ie/ publications/TheDistributionallmpactOflrelands IndirectTaxSystem_2006.pdf.

Bird, R. M., \& Zolt, E. M. (2008). Technology and Taxation in Developing Countries: From Hand to Mouse. UCLA Law Review, 52(6), 1627-1695. https://dx.doi.org/10.2139/ssrn. 1086853.

Bird, R., \& Zolt, E. (2014). Redistribution via Taxation: The Limited Role of the Personal Income Tax in Developing Countries. Annals of Economics and Finance, 15(2), 625-683.

Blundell, R., \& Bond, S. (1998). Initial Conditions and Moment Restrictions in Dynamic Panel Data Models. Journal of Econometrics, 87(1), 115-143. https://dx.doi.org/10.1016/ S0304-4076(98)00009-8.

Bye, B., Strøm, B., \& Åvitland, T. (2012). Welfare Effects of VAT Reforms: A General Equilibrium Analysis. International Tax and Public Finance, 19(3), 368-392. https://dx.doi. org/10.1007/s10797-011-9193-9.

Chen, W., \& Kinkyo, T. (2016). Financial Development and Income Inequality: Long-Run Relationship and Short-Run Heterogeneity. Emerging Markets Finance and Trade, 52(3), 733-742. https://dx.doi.org/10.1080/1540496X. 2016.1116281.

Chong, A., \& Calderón, C. (2000). Institutional Quality and Income Distribution. Economic Development and Cultural Change, 47(4), 761-786. https://dx.doi.org/10.1086/452476.

Doytch, N., \& Uctum, M. (2011). Does the Worldwide Shift of FDI from Manufacturing to Services Accelerate Economic Growth: A GMM Estimation Study. Journal of International Money and Finance, 30(3), 410-427. https://dx.doi.org/10.1016/j.jimonfin.2011.01.001.

Everest-Phillips, M., \& Sandal, R. (2009). Linking Business Tax Reform with Governance: How to Measure Success [World Bank Other Operational Studies Number 10572]. Retrieved February 1, 2016, from https://openknowledge.worldbank.org/
bitstream/handle/10986/10572/483140BRIOlink 10Box338894B01PUBLIC1.pdf?sequence=1.

Gupta, S., Davoodi, H., \& AlonsoTemme, R. (2002). Does Corruption Affect Income Inequality and Poverty? Economics of Governance, 3(1), 23-45. https://doi. org/10.1007/s101010100039.

Hájek, L. (2001). Tax Reform in New Zealand and Its Tendency in OECD Countries. Ekonomický časopis, 49(2), 318-329.

Imam, P. A., \& Jacobs, D. F. (2007). Effect of Corruption on Tax Revenues in the Middle East [IMF Working Papers Number 07/270]. Washington, DC: International Monetary Fund, Washington, DC.

In'airat, M. (2014). Aid Allocation, Selectivity, and the Quality of Governance. Journal of Economics, Finance and Administrative Science, 19(36), 63-68. https://doi.org/10.1016/j.jefas.2014.03.002.

Keen, M., \& Lockwood, B. (2010). The Value Added Tax: Its Causes and Consequences. Journal of Development Economics, 92(2), 138-151. https://dx.doi.org/10.1016/j.jdeveco. 2009.01.012.

Keen, M., \& Mintz, J. (2004). The Optimal Threshold for A Value-Added Tax. Journal of Public Economics, 88(3-4), 559-576. https://dx.doi.org/10.1016/S0047-2727(02)00165-2.

Knight, J., \& Sabot, R. (1983). Educational Expansion and the Kuznets Effect. American Economic Review, 73(5), 1132-1136.

Kwabena, G. B. (2002). Corruption, Economic Growth, and Income Inequality in Africa. Economics of Governance, 3(3), 183209. https://doi.org/10.1007/s101010200045.

Kyriacou, A. P., Muinelo-Gallo, L., \& RocaSagales, O. (2017). Regional Inequalities, Fiscal Decentralization and Government Quality. Regional Studies, 51(6), 945-957. https://dx.doi.org/10.1080/00343404.2016.1150992.

La Porta, R., López-de-Silanes, F., Shleifer, A., \& Vishny, R. (1999). The Quality of Government. Journal of Law, Economics and Organization, 15(1), 222-279. https://dx.doi. org/10.1093/jleo/15.1.222.

Leahy, E., Lyons, S., \& Tol, R. S. J. (2011). The distributional effects of value added tax in Ireland. Economic and Social Review, 42(2), 213-235.

Li, H., Xu, L. C., \& Zou, H. F. (2000). Corruption, Income Distribution, and Growth. Economics and Politics, 12(2), 155-181. https://dx.doi.org/10.1111/1468-0343.00073. 
Magu, M. C. (2013). The Relationship between Government Revenue and Economic Growth in Kenya. International Journal of Social Sciences and Project Planning Management, 1(1), 87-109.

Martinez-Vazquez, J., Moreno-Dodson, B., \& Vulovic, V. (2012). The Impact of Tax and Expenditure Policies on Income Distribution: Evidence from a Large Panel of Countries [International Center for Public Policy Working Paper Series. Paper 77]. Retrieved February 1, 2016, from http://scholarworks.gsu.edu/icepp/77.

Mauro, P. (1997). Why Worry About Corruption? Economic Issues, 6. Washington D.C.: International Monetary Fund.

Milanovic, B., \& Squire, L. (2007). Does Tariff Liberalization Increase Wage Inequality? Some Empirical Evidence. In NBER Chapters in Globalization and Poverty (pp. 143-182). https://dx. doi.org/10.7208/chicago/9780226318004.003.0005.

Mitchell, D. J. (2005). Beware the valueadded tax. In Backgrounder: The Heritage Foundation, 1852 (pp. 1-11).

Muinelo-Gallo, L., \& Miranda, A. R. (2014). Fiscal Decentralization, Governance Quality, and Regional Disparities in Uruguay. Estudios De Economia, 41(2), 219-250.

Musa, R. (2014). Household Expenditure Components and the Poverty and Inequality Relationship in Malawi. African Development Review-Revue Africaine De Développement, 26(1), 138-147. https://dx.doi.org/10.1111/14678268.12070.

Narayanan, S. (2014). The Impact of the Goods and Services Tax (GST) in Malaysia: Lessons from Experiences Elsewhere (A Note). Singapore Economic Review, 59(2). https://dx.doi.org/10.1142/S021759081450009X.

OECD. (2012). Reducing Income Inequality While Boosting Economic Growth: Can It Be Done? Economic policy reforms 2012: Going for growth, Part II Chapter 5. https://dx.doi. org/10.1787/growth-2012-47-en.

Poblete, C. M. (2010). Evaluating Tax Reforms in Chile with a CGE Model. Estudios De Economia, 37(2), 243-284.

Richupan, S. (1984). Income Tax Evasion: A Review of the Measurement of Techniques and Some Estimates for the Developing Countries [Department of Memorandum No. DM/84/46]. Washington, D.C.: International Monetary Fund.

Saez, E. (2004). Direct or Indirect Tax Instruments for Redistribution: Short-Run versus Long-Run. Journal of Public Economics,
88(3-4), 503-518. https://dx.doi.org/10.1016/ S0047-2727(02)00222-0.

Shafique, S., \& Haq, R. (2006). Governance and Income Inequality. Pakistan Development Review, 45(4), 751-760.

Sumarto, S., Arifianto, A., \& Suryahadi, A. (2003). Governance and poverty reduction: evidence from newly decentralized Indonesia. In Y. Shimomura (Ed.), The Role of Governance in Asia (pp. 27-64). Singapore: Institute of Southeast Asian Studies. https://dx.doi. org/10.2139/ssrn.858484.

Tait,A. (1991). Value-Added Tax:Administrative and Policy Issues [IMF Occasional Paper No. 88]. Washington, D.C.: International Monetary Fund. https://dx.doi.org/10.5089/9781557751843.084.

Tanzi, V. (1977). Inflation, Lags in Collection and the Real Value of the Tax Revenue. IMF Staff Papers, 24(1), 154-167. https://dx.doi.org/ 10.2307/3866540.

Tanzi, V., \& Chu, K. (1992). La Political Fiscal Para Un Crecimiento Estable $Y$ Equitativo En Amèrica Latina. In L. Montuschi, \& H. Singer (Eds.), Los Problemas del Desarollo en Amèrica Latina-Homenaje a Raúl Prebisch (pp. 363-403). Beunos Aires: Dondo de Cultura Económica.

Tanzi, V., \& Davoodi, H. R. (1997). Corruption, Public Investment, and Growth [IMF Working Paper No 97/139]. Washington, D.C.: International Monetary Fund. https://dx.doi. org/10.5089/9781451929515.001.

Yang, S. P., \& Zhou, M. (2011). Study of the Tax Policy of Adjusting the Income Gap between Urban and Rural Areas: Based on the Perspective of China's Indirect Tax. Financial Research, 7, 72-74.

Zhang, J. (1996). Optimal Public Investments in Education and Endogenous Growth. Scandinavian Journal of Economics, 98(3), 387-404. https://dx.doi.org/10.2307/3440733.

Sok-Gee Chan, Ph.D.

University of Malaya

Faculty of Business and Accountancy Department of Finance and Banking Malaysia sokgee@um.edu.my

Zulkufly Ramly International Islamic University Malaysia Kulliyah of Economics and Management Sciences

Department of Finance Malaysia zul_ramly@iium.edu.my 


\section{Abstract}

\section{THE ROLE OF COUNTRY GOVERNANCE ON VALUE-ADDED TAX AND INEQUALITY}

\section{Sok-Gee Chan, Zulkufly Ramly}

Income inequality is a growing concern for regulators because it brings adverse consequences towards social stability, institutional stability and economic performance. One of the popular ways to reduce income inequality is through the implementation of Value Added Tax (VAT) despite of many criticisms on its regressive nature. Hence, using a wide data range from 1984 to 2014, we study the impact of VAT on income inequality in both developed and developing countries. Besides, this is the first study that seeks to focus on the moderating role of country governance in enhancing the effect of VAT on income inequality. We use the Generalized Method of Moments (GMM) to overcome the endogeneity, autocorrelation and heteroscedasticity issues. The results suggest that the VAT reduces income inequality but the positive effect is contingent upon the existence of a set of good country governance. Countries that have higher quality of bureaucracy, greater democratic accountability, high government stability, effective law and order, low political risk and favourable socioeconomic conditions stand to benefit more from the VAT system in terms of narrowing the income inequality. Therefore, we conclude that better institutions improve the tax collection and public service delivery, which is a crucial element in achieving the economic objective of narrowing the income gap between the wealthy and the poor. This is particularly true in developing countries. Further, the governments in developing countries need to effectively manage the degree of socioeconomic pressure that could distract them from implementing social and economic policies to eradicate poverty and raise the income level of the poor segment of society.

Key Words: Income inequality, value added tax, tax distribution, country governance, Generalized Method of Moments (GMM).

JEL Classification: C23, E62, H21, H2, O43.

DOI: 10.15240/tul/001/2018-4-006 